\title{
Szemmozgásos traumafeldolgozás (EMDR-terápia): Hatás, hatásmechanizmus, hatásosság
}

\author{
SZIGETI F. JUDIT \\ Semmelweis Egyetem, Klinikai Pszichológia Tanszék, Budapest
}

(Beérkezett: 2018. március 11.; elfogadva: 2018. július 9.)

Elméleti háttér: Az EMDR (Eye Movement Desensitization and Reprocessing) mint pszichoterápiás módszer harminc éve létezik. A Francine Shapiro által az 1980-as évek második felében az Egyesült Államokban kidolgozott eljárás kezdetben sok vitát kavart, de ma már bizonyítékokon alapuló módszernek számít a poszttraumás stressz zavar (PTSD) kezelésében. Használata számos más mentális betegség (pl. pánikzavar, depresszió, kényszerbetegség) gyógyításában is egyre gyakoribb. Magyarországon a módszer még kevéssé terjedt el. Cél: Bemutatni az EMDR-terápia történetét, elméleti hátterét, a hatásmechanizmusára vonatkozó hipotéziseket, a kezelés struktúráját és hatásait. Módszerek: Szakirodalmi áttekintés az angol nyelvú adatbázisok (ISI Web of Science, PubMed, Scopus, PsycINFO) alapján, az eljárás nevével történt szisztematikus kulcsszókereséssel. Az áttekintés lehetőség szerint összefoglaló vagy magas evidenciaszintú (randomizált kontrollált) vizsgálatokra alapoz. Eredmények: EMDR során deszenzitizáció, a traumás emlékekhez való jobb hozzáférés és mélyebb információfeldolgozás történik, ami nemcsak stresszcsökkentést, hanem adaptívabb, magasabb szintú múködést eredményez. Képalkotó eljárásokkal kimutatható, hogy az EMDR specifikus hatótényezője, a bilaterális ingerlés, egyebek közt paraszimpatikus túlsúlyt eredményez, és kedvező változásokat idéz elő a PTSD által érintett agyi struktúrák múködésében. Az EMDR hatásmechanizmusáról számos hipotézis született (pl. dekondicionálás-, munkamemória-, REM-hipotézis), mindazonáltal, az eljárásban valószínúleg több aktív komponens van jelen. Sikeres EMDR-terápia hatására a személy napirendre tér az életútját megakasztó események felett, és egységes narratívába emeli őket, amely hozzájárulhat személyisége integrációjához. Következtetések: Az EMDR nemcsak ismert és eredeti terápiás elemek újszerú kombinációja, nem is a már meglévő traumakezelési eljárások technikai kiegészítése, hanem bizonyítottan hatékony, teljes értékú, integratív, mégis önálló pszichoterápiás módszer, saját elméleti modellel, hatásmechanizmussal és eszköztárral.

Kulcsszavak: pszichotrauma, poszttraumás stressz zavar, szemmozgásos deszenzitizáció és újrafeldolgozás, EMDR, pszichoterápia

Levelezési cím: Szigeti F. Judit, Semmelweis Egyetem, Klinikai Pszichológia Tanszék, 1083 Budapest, Tömő u. 25-29. III. emelet. E-mail: szigetifjudit@gmail.com 


\section{Az EMDR mibenléte és rövid története}

Becslések szerint több száz pszichoterápiás módszer létezik a világon, és egyre-másra jelennek meg újabbnál újabbak. Nem csoda, ha a képződni vágyó szakember a bőség zavarával küzd, és némi szkepticizmussal viszonyul a növekvő kínálathoz. Jelen tanulmány célja a szemmozgásos deszenzitizáció és újrafeldolgozás vagyis az EMDR (Eye Movement Desensitization and Reprocessing) néven ismert terápiás módszer bemutatása, mintegy megkönnyítendő az érdeklődő magyar szakember számára a tájékozódást.

Az EMDR-terápia elsődlegesen a traumák feldolgozását elősegítő módszer: ez volt és ma is ez a fó célja. A Francine Shapiro által az 1980-as évek második felében kidolgozott eljárás ma már bizonyítékokon alapuló (evidence-based) módszernek számít a poszttraumás stressz zavar (PTSD) kezelésében. Az EMDR-t standard eljárásként javasolja - a traumafókuszú kognitív viselkedésterápia mellett - az Egészségügyi Világszervezet (World Health Organization, 2013) és a NICE (a brit egészségügyi ellátás módszertani intézete; National Institute for Health and Care Excellence, 2005), valamint ajánlott eljárásként hivatkozik rá az Amerikai Pszichológiai Társaság (American Psychological Association, 2017).

Mint sok más tudományos felfedezés, az EMDR is tapasztalati úton jött létre. Ahogy megalkotója közzéteszi magyarul is hozzáférhetó ismeretterjesztő könyvében (Shapiro, 2016), egy megterhelő eseményt követő séta után arra lett figyelmes, hogy a parkból kijőve sokkal jobban érzi magát, mint előtte. Visszatérve észrevette, hogy séta során a szeme ide-oda cikázik az ösvényt szegélyezó párhuzamos fasor lombkoronái között, és felmerült benne, hogy a sajátos szemmozgásnak talán köze lehet a megkönnyebbüléshez. Hipotézisét először barátokon és ismerősökön ellenőrizte, s mivel a célszemélyeknek nehezükre esett spontánul produkálni a szemmozgást, két ujját a szemük előtt jobbra-balra mozgatva ő maga indukálta azt. Az eljárást pontosította, finomította, majd hatásosságát háborús veteránokon, nemi erőszakon átesett vagy gyermekkorban szexuális abúzust elszenvedett személyeken próbálta ki, és írta le először (Shapiro, 1989).

Az azóta végzett több mint húsz randomizált kontrollált vizsgálat egyértelmúen bizonyítja az EMDR hatásosságát PTSD esetén (Chen és mtsai, 2014). Egyszeri vagy többszörös traumák esetén akár 3-6 ülés alatt 77100\%-os remisszió érhető el (Högberg és mtsai, 2007; Konuk és mtsai, 2006; Marcus, Marquis, \& Sakai, 1997; 2004). A hatás legalább egyenértékú a kognitív viselkedésterápiáéval (pl. traumafókuszú CBT, expozíciós terápia) (Seidler \& Wagner, 2006; Watts és mtsai, 2013), ugyanakkor gyorsabb (Jaberghaderi, Greenwald, Rubin, Dolatabadim, \& Zand, 2004; Power és mtsai, 2002). A PTSD kezelésében az EMDR hatásosabbnak bizonyult a farmakoterápiánál (fluoxetine-nél) is (van der Kolk és mtsai, 2007). Gyer- 
mekkori rossz bánásmód hatására kialakuló ún. kötődési (Fonagy, Gergely, Jurist, \& Target, 2002), komplex (Herman, 2003), vagy fejlődési (van der Kolk és mtsai, 2009) traumatizáció esetében azonban ezzel a módszerrel is hosszabb terápiára van szükség.

Egyre-másra születnek vizsgálatok az EMDR alkalmazásáról más olyan pszichés zavarok esetén is, amelyek hátterében megterhelő életesemények húzódhatnak meg (pl. fóbiák, pánikzavar, reaktív depresszió, függőségek, disszociációs zavarok). Ezek EMDR-rel történő gyógyítását alkalmazott protokollok segítik, egyesek hatásosságát már randomizált kontrollált vizsgálatok is igazolják (Horst és mtsai, 2017; Ostacoli és mtsai, 2018).

\section{Az EMDR elméleti háttere}

Felfedezését Shapiro (1989) először a deszenzitizációs modellel magyarázta, miszerint a szemmozgások félelemcsökkenést idéznek elő (ekkor még csak $E M D$-ról, azaz szemmozgásos deszenzitizációról beszélt). Később megfigyelte, hogy a hatás nemcsak affektív, hanem kognitív területen is bekövetkezik - például spontán módosulás történik a traumatikus esemény értelmezésében -, így később egy információfeldolgozási és memóriamodellbe ágyazta a módszerét (ekkor született az EMDR elnevezés, amely a deszenzitizáció mellett az újrafeldolgozási elemet is tartalmazza). A Shapiro (2001) által leírt ún. adaptív információfeldolgozási modell lényege, hogy az ember egy eseményt úgy tárol az emlékezetében, hogy észleleti, érzelmi, testérzésbeli és gondolati összecsengések alapján korábbi történések emlékhálózataihoz kapcsolja (adaptív tárolás). Ha azonban az esemény átélését nagyfokú stressz övezi, ez akadályozza az új tapasztalat belesimulását a memóriahálózatba, a feldolgozás elakad, az emlékek pedig ugyanabban a nyers formában rögzülnek, ahogyan kódolásuk megtörtént (maladaptív tárolás). Az elmélet szerint ez az alapja a diszfunkcionális gondolatoknak, érzelmeknek és viselkedéseknek, amelyek aztán a traumatikus élmény újrafeldolgozásával gyógyíthatók. E modell alkalmas arra, hogy segítségével az EMDR-terápiát elméleti keretbe helyezzük, ugyanakkor leíró jellegú, spekulatív, és önmagában még semmit sem árul el arról, hogy valójában mi történik az EMDR-terápia során.

\section{Az EMDR múködése - hipotézisek és bizonyítékok}

A hatékonyságvizsgálatok tehát mára már kétség nélkül bizonyították, hogy az EMDR eredményesen kezeli a PTSD tüneteit. Ugyanakkor ezek az összehasonlítások nem alkalmasak arra, hogy rávilágítsanak a terápia pon- 
tos hatásmechanizmusára. Bőséggel állnak rendelkezésre azonban olyan vizsgálatok is, amelyek épp az utóbbi feltárását túzték ki célul. Ezek két csoportra oszthatók: az elsőbe tartoznak a leíró, a másodikba a magyarázó jellegú kutatások. A most következő áttekintés ezek legfontosabbjairól nyújt összefoglalást.

\subsection{Mi zajlik az EMDR során és után? Leíró vizsgálatok}

A PTSD diagnosztikai kritériumai egyebek közt intruzív és fokozott készenléttel kapcsolatos tüneteket is magukban foglalnak (American Psychiatric Association, 2013). Elvárható ezért, hogy egy olyan terápia során, amely a PTSD tüneteit hivatott enyhíteni, sajátos aktivitás mutatkozzék az érintett kognitív és vegetatív múködésekhez köthetó agyi területeken.

Valóban: SPECT-vizsgálattal kimutatható, hogy PTSD-ben szenvedő alanyok agyában EMDR-terápia után a kezelés előttihez képest nagyobb aktivitás mutatkozik az anterior cinguláris gyrusban és a bal frontális lebenyben, ami a figyelmi, a végrehajtó és egyéb kognitív funkciók javulását jelzi (Levin, Lazrove, \& van der Kolk, 1999). Ezen kívül csökken az aktivitás a hippokampális-temporális lebenyben, ami a készenléti (hyperarousal) állapot és a hipervigilancia enyhülését mutatja (Oh \& Choi, 2007). Hasonlóképpen, kisebb tevékenység észlelhetó a vizuális-okcipitális lebenyben, ami a flashback-ek csökkenő gyakoriságát tükrözi (Lansing, Amen, Hanks, \& Rudy, 2005). Az EEG-vizsgálatok eredményei is jelzik, hogy - az EMDRülések előrehaladtával - a traumás ${ }^{1}$ emlék szemmozgásos felidézésekor az idegi aktivitás eltolódik a limbikus valenciájú prefrontális régiókból a kognitívabb területekre (Pagani és mtsai, 2015), ami az érzelmi megterhelés enyhülését jelzi. Egy funkcionális MRI-vizsgálat eredményei szerint pedig - szemmozgásokat követően - a traumás emlék felidézése alacsonyabb amigdala és rosztrális anterior cinguláris kéreg konnektivitást eredményezett, mint előtte (Thomaes, Engelhard, Sijbrandij, Cath, \& Van den Heuvel, 2016), ami szintén az érzelmi feldolgozódás irányába mutat.

A modern képalkotó vizsgálatok tehát azt mutatják, hogy az EMDRterápia hatására zajló idegrendszeri folyamatok összhangban állnak a PTSD tüneteinek csökkenésével.

\footnotetext{
${ }^{1}$ A tanulmány során a Herman (2003) múvének fordítása során alkalmazott szóhasználati ajánlást követtem, amely szerint a traumatikus kifejezést "traumát okozó", a traumás szót pedig "traumával kapcsolatos" (ld. pl. poszttraumás stressz) értelemben javasolt használni.
} 


\subsection{Hogyan fejti ki hatását az EMDR? Magyarázó kutatások}

Az EMDR-terápiát számos kritika érte, amely általában arról szólt, hogy az EMDR nem több a hagyományos expozíciós vagy traumafókuszú kognitív terápiánál, és a különleges ismertetőjegyként számon tartott szemmozgásoknak legfeljebb placebohatásuk van (Davidson \& Parker, 2001). Eszerint a szemmozgás - stílusosan szólva - nem volna más, mint szemfényvesztés. "Ami az EMDR-ben hatásos, az nem új, ami pedig új, az nem hatásos" szólt a kritika (Salkovskis, 2002, 13. o.). Valójában egy gyógyító módszert gyakran használnak úgy, hogy még nem ismerik a hatásmechanizmusát: az aszpirint például már 1899 óta alkalmazták, miközben csak 1971-ben jöttek rá, mitől hat (Bergmann, 2010). A szkeptikus hangok első megszólalása óta metaanalízis bizonyította, hogy a szemmozgást alkalmazó EMDRbeavatkozásoknak nagyobb a hatásméretük, mint az azt nélkülözőknek, ami leginkább a negatív emlékképek megfakulásában érhető tetten (Lee \& Cuijpers, 2013). A kritikus hozzáállás tehát megtermékenyítóleg hatott az EMDR hatásmechanizmusának felderítését célzó kutatómunkára: alig van még olyan pszichoterápiás módszer, amelynek fizikai vetületeiről ennyi tényszerú információ gyúlt volna össze.

Az EMDR hatásmechanizmusáról számos hipotézis született, amelyek közül jelen tanulmányban ötöt tekintünk át röviden.

\subsubsection{A kölcsönös gátlás hipotézis}

Az EMDR specifikus hatótényezője az eljárás nevében is megtalálható vizuális (eye movement) - esetleg auditív vagy taktilis - bilaterális stimuláció (BLS), vagyis olyan fizikai ingerlés, amit a páciens valamely érzékszervi modalitásban (látás, hallás, tapintás) a két testfélre felváltva kap. Az EMDR múködéséról szóló hipotézisek mind arról állítanak valamit, hogy a traumatikus esemény BLS-sel egyidejú irányított felidézése hogyan mozdítja elő a tünetek csökkenését és azt, hogy a traumáról alkotott felfogás pozitívan változzon.

A kölcsönös gátlás hipotézis szerint a traumás emlék felidézése szimpatikus idegrendszeri, azaz szorongásos választ indukál, miközben a BLS paraszimpatikus, azaz relaxációs választ vált ki a páciensből, és ez a két hatás fokozatosan kioltja egymást (Wilson, Silver, Covi, \& Foster, 1996).

A kétoldali alternáló ingerlésre adott relaxációs válaszra több bizonyíték is született: azt találták például, hogy BLS alatt csökken a pulzusszám, azaz vagális túlsúly alakul ki (Eloffson, von Scheele, Theorell, \& Söndergaard, 2008). Hasonlóképpen, fokozódik a szívritmus-variabilitás (Sack, Lempa, \& Lamprecht, 2007), vagyis a szorongásos állapothoz képest - amelyben a 
szívfrekvencia tartósan és változatlanul magas marad - a szív visszanyeri egészséges, rugalmas reakcióképességét. Ugyancsak paraszimpatikus tónusra utal az az eredmény, miszerint EMDR-kezelés során csökken a bőr vezetóképessége (Barrowcliff, Gray, Freeman, \& MacCulloch, 2004), vagyis a szorongásra utaló verejtékezés. E hipotézis alapján az EMDR más expozíciós terápiákhoz (Wolpe, 1990) hasonlóan múködhet, amelyek az ijesztő emlékekkel való szembesülést relaxációs válasszal kötik össze, ezzel dekondicionálva a szorongásos reakciót.

\subsubsection{Az orientációsreflex-hipotézis}

Az orientációsreflex-hipotézis szerint a bilaterális stimuláció a páciensból az új ingerekhez való automatikus odafordulást, azaz orientációs reflexet vált ki. Ezzel párhuzamosan a páciens felidézi a traumás emléket, amelynek negatív tartalma (potenciális veszélyessége) nyugtalansággal tölti el. A pozitív viszcerális aktivációval járó orientációs tevékenység során azonban a páciens azt észleli, hogy nincs valódi, jelenlévő veszély, így az arousalszint csökken (MacCulloch \& Feldman, 1996).

Fontos megjegyezni, hogy az orientációs válasz (orientation response) nem tévesztendő össze az ún. összerezzenés- (startle response), illetve védekező reflexszel (defensive response). Utóbbiak megijedéssel és annak fizikai korrelátumaival (szimpatikus válasszal) járó reakciók egy váratlan ingerre, például megriadunk, ha egy koncertteremben, elmélyült zenehallgatás közben valaki hirtelen leejt mellettünk egy súlyos tárgyat. Az orientációs válasz ezzel szemben az új ingerre adott nyugodt ráfigyelő reakció, aktív felfedező magatartás: ha például valaki a koncerten csendben belép az ajtón, általában automatikusan, lazán odafordulunk, és ránézünk a bejövőre. E hipotézis szerint az EMDR emlékközömbösító hatása éppen az orientációs reflexnek ezzel az elengedetten, érdeklődő jellegével függhet össze.

A kölcsönös gátlás hipotézist alátámasztó, paraszimpatikus válaszra utaló adatok áttételesen az orientációsreflex-hipotézist is igazolhatják. Közvetlen bizonyítékként pedig azt találták, hogy EMDR után csökken a P3a vagyis az újszerú, váratlan ingerekre megjelenő, EEG-vel mérhetó eseményhez kötött potenciál összetevő aktivitása az EMDR alattihoz képest (Lamprecht és mtsai, 2004). Ugyanakkor megjegyzendő, hogy BLS alatt olyan hatások is jelentkeznek, amelyek éppen szimpatikus aktivitásra utalnak: emelkedik például az ujjak hőmérséklete és a légzésfrekvencia (Elofsson, von Scheele, Theorell, \& Söndergaard, 2008). 


\subsubsection{Az agyféltekeinterakció-hipotézis}

Az emlékezet múködésének egyik fontos felfedezése, hogy míg a szemantikus emlékeknek mind a kódolásáért, mind az előhívásáért a bal agyfélteke felelős, addig az epizodikus emlékek kódolása a bal, előhívása viszont a jobb agyféltekében zajlik (Tulving, Kapur, Craik, Moscovitch, \& Houlet, 1994). Régi észrevétel, hogy PTSD esetén az epizodikus emlékezet érintett. Az egyik magyarázat szerint ez azért van, mert a traumatikus események leginkább észleletek, azaz képek, hangok, szagok, testérzetek formájában, valamint az óket kíséró erőteljes érzelmekkel együtt fragmentáltan, dezorganizáltan kódolódnak a memóriában, és nem lesz belőlük egységes, koherens narratíva, mint a semleges életeseményekből (van der Kolk \& Fisler, 1996). Az interhemiszferális interakció hipotézis szerint az EMDR, amelynek során mindkét oldali testfél ingerlődik, a corpus callosumon keresztül élénkíti a jobb és bal agyfélteke közti kommunikációt, ami kedvez a traumás emlékek és asszociált tartalmak epizodikus előhívásának és feldolgozásának (Propper \& Christman, 2008). A hipotézis megalkotói szerint az EMDR legalább két szinten hat: 1) oldja az epizodikus memória diszfunkcióit, és 2) semlegesíti az immár élénkebben felidézett traumás emlékek okozta negatív érzelmi állapotot.

A klinikai tapasztalat valóban azt mutatja, hogy a kezelés során a kliens egyre jobban hozzáfér traumás emlékeihez. Mindazonáltal úgy túnik, a kísérő negatív érzelmek oldódása nem feltétlenül az agyféltekék közti jobb információáramlásnak tulajdonítható. Egy egyszerú kísérlet eredménye ugyanis azt mutatta, hogy a vertikális szemmozgás éppen olyan hatásosan csökkenti a rossz emlékek érzelmi töltetét, mint a horizontális (Gunter \& Bodner, 2008). Úgy tünik tehát, hogy ez a tetszetős hipotézis nem teljesen állja meg a helyét.

\subsubsection{A munkamemória-hipotézis}

A munkamemória-hipotézis azt feltételezi, hogy a traumás emlék felidéztetése és a BLS követése együtt ún. kettős-feladat (dual task) helyzetet idéz eló, amelyben a munkamemória túl nagy igénybevételnek van kitéve (Hornsveld és mtsai, 2010). Így ismételt felidézéskor a félelmetes emlékre kevesebb figyelem jut, ezért csökken a felidézőre gyakorolt hatása (Gunter \& Bodner, 2008).

A kognitív pszichológia jeles képviselői igyekeztek választ találni mind analóg (egészséges mintán zajló), mind pedig klinikai kísérletek útján arra, hogy ez a túlterhelődés a munkamemória melyik területén jön létre. Az egyik elképzelés szerint a szemmel követendő ingerek a vizuális-téri 
jegyzettömb szintjén dolgoztatják meg a munkamemóriát (Andrade, Kavanaugh \& Baddeley, 1997). A másik feltételezés szerint mind a központi végrehajtó, mind pedig az alacsonyabb, modalitásra specifikus szintek is érintettek lehetnek, hiszen a megosztott figyelem a központi végrehajtónak, az emlékelóhívás pedig az epizodikus tárnak ad tennivalót (Gunter \& Bodner, 2008).

Számos kutatás látszik alátámasztani a munkamemória-hipotézis helytállóságát. A hatás eléréséhez arra van szükség, hogy az interferáló feladat kellően igénybe vegye a munkamemória limitált kapacitását. Valóban: a gyors szemmozgás - ami jobban megdolgoztatja a munkamemóriát - erőteljesebb deszenzitizáló hatást eredményez a lassúnál (Maxfield, Melnyk, \& Gordon Hayman, 2008), és a passzívabb feladatok (például sípoló hang befogadása) kevésbé hatásosak a szemmozgásnál (Van den Hout és mtsai, 2011). Továbbá, a szemmozgás csak akkor jár megkönnyebbüléssel, ha a rossz emlék felidézésével egyidejúleg, és nem előtte vagy utána zajlik (Gunter \& Bodner, 2008). Ezen kívül dózis-válasz összefüggés is mutatkozik a munkamemória-feladat nagysága és hatásossága között (Engelhard, Van den Hout, \& Smeets, 2011).

Egy előhívott emlék rekonszolidációja két szakaszban zajlik: a destabilizáció (1. szakasz) során az emlék újra labilissá válik, majd hat óra áll rendelkezésre, hogy további fehérjeszintézis útján restabilizálódjon (2. szakasz), azaz újra megszilárduljon (Nader, Schafe, \& Le Doux, 2000). PTSD-vel élő személyeknél ez a folyamat elakad. A traumaemlékeztetők okozta félelmi reakciók nem oltódnak ki, így az emlék rekonszolidációja is törést szenved (Smith, Doran, Sippel, \& Harpaz-Rotem, 2017). Úgy túnik, hogy az emlék felidéződésével egyidejú BLS a munkamemória párhuzamos megdolgoztatásával hozzájárul a traumaemlékek labilissá válásához, a félelmi reakció kioltódásához, esélyt nyújtva arra, hogy reprezentációja kedvező irányba módosuljon. Így az emlék kevésbé ijesztő formában „,tanulódik újra”: veszít élénkségéből és érzelmi töltetéből, és új minőségét a következő felidézésig is megtartja.

A munkamemória-hipotézis egyike a legjobban bizonyított feltételezéseknek, magyarázatot nyújtva az emlékekre való érzékenység csökkenésére. Azonban EMDR-terápia során ennél több történik: át is értékelődik a rossz tapasztalat.

\subsubsection{A REM-hipotézis}

Ezen a ponton az érthetőség kedvéért ki kell térnünk arra, hogyan válnak a történések emlékekké, és mi köze van ehhez az alvásnak. Amikor részesei vagyunk egy eseménynek, arról észlelet keletkezik a szenzoros agykérgekben. A perceptuális reprezentációs rendszerből az információk azonnal át- 
kerülnek a hippokampuszba. A kódolt tartalmakat az epizodikus emlékezeti rendszerben tároljuk. Ebben a folyamatban a hippokampusz és a kéreg kapcsolata mellett az amigdala is szerepet játszik, az érzelmi asszociációk rögzítése révén. Mivel azonban napközben folyamatosan történik velünk valami, mélyebb feldolgozásra csak akkor kerülhet sor, amikor az agy „lekapcsol", és újabb információt már alig kell befogadnia: azaz alvás közben. Az alvás ún. non-REM fázisa alatt - amelyre a 0,5-4 Hz frekvenciájú delta agyhullámok jellemzők - megkezdődik az információk lassú konszolidációja. Ennek során az emlékinformációk az epizodikus memóriából a szemantikus tárba, vagyis a hippokampusztól függetlenedve, a neokortexbe kerülnek át. Később az agy a REM-alvás során - amely alatt 4-8 Hz frekvenciájú théta hullámokat generál - a kapott információból kivonja az általánosítandó tartalmakat, azok tágabb kontextusba kerülnek, így "tanulunk az eseményból", vagyis az emlék integrálódik a memóriatárházba. Ezzel párhuzamosan megtörténik az epizodikus emlék visszacsatolásos elhalványulása, mivel a neokortex utasításokat küld a hippokampusznak, hogy az esetleges, egyedi információk nyugodtan elfelejthetők, így az epizodikus memóriában hely szabadul fel további események megőrzése számára (Stickgold, 2002).

Az EMDR ún. REM-hipotézise azon az egyszerú párhuzamon alapul, amely az alvás REM-fázisa és az EMDR során indukált vízszintes, oldalirányú szemmozgások között van. Ebból született az elképzelés, hogy a BLS a figyelem folyamatos reorientációján keresztül acetilkolint szabadít fel, ami aktiválja a REM-szerú fiziológiai rendszereket (Stickgold, 2002). Ezt látszik bizonyítani, hogy a BLS során nemcsak paraszimpatikus, hanem kolinerg aktiváció is zajlik: emelkedik az ujjak hőmérséklete és a légzésfrekvencia, hiperkapnia és hipoxémia áll be, amely jelenségek az alvás REM-fázisára is jellemzők (Elofsson és mtsai, 2008). A hipotézis alapján a BLS ugyanazokat az információfeldolgozási folyamatokat katalizálja az agyban, mint a REMalvás, ezzel segítve az emlékek feldolgozását.

Összességében nem valószínú, hogy bármelyik fentebb tárgyalt mechanizmus önmagában felelős volna az EMDR összes pozitív hatásáért. Egy friss áttekintő tanulmány szerint az eljárás biológiai alapjairól szóló hipotézisek bizonyos fokig még mindig spekulatívak, ám ez elmondható általában a pszichoterápiáról (Navarro és mtsai, 2018). Az eljárásban minden bizonynyal több aktív komponens van jelen (Gunter \& Bodner, 2009).

\section{Az EMDR-kezelés struktúrája}

Az EMDR múködéséről összegyúlt tudás áttekintése után essék szó röviden az EMDR-terápia szerkezetéről (részletesebb áttekintésért ld. Havelka, 2015). A folyamat leírását egy terápiás eset részletei szemléltetik. 
A 22 éves egyetemi hallgatót poszttraumás stressz zavar iránydiagnózissal küldi a diáktanácsadó pszichológusa, aki szakmai körökben értesült az EMDRterápiáról. A rendelésen szép, filigrán, introvertált, könnyen elérzékenyülö fiatal nő jelenik meg. Pannát 13 évesen autóbaleset érte: egy ittas vezetö ütötte el, jobb lábán számos törést szenvedett, másfél hónap múlva tudott csak lábra állni mankóval. Az iskolában nem kellett halasztania, életvitele fokozatosan rendeződött. 15 éves korában meg kellett jelennie egy, a balesettel kapcsolatos tárgyaláson. Ez lelkileg felkavarta, 4-5 alkalmas pszichoterápián vett részt a nevelési tanácsadóban, egyébiránt pszichiátriai anamnézise eseménytelen. Az EMDR-terápián való megjelenése előtt néhány hónappal elhatározta, hogy jogositványt szerez. Elsősegélynyújtás-, KRESZ- és rutinvizsgáját sikeresen letette, a forgalomban való vezetéskor azonban egy keresztezödésben annyira leblokkolt, hogy az oktatónak kellett átvennie a kormányt. Ezután abba is hagyta a vezetéstanulást. Jelentkezéskor utasként is alig mer autóba ülni. A járdán is összerezzen, amikor autó halad el mellette, és csak akkor mer átmenni a lámpa nélküli zebrán, ha autó a távolban sincsen. Ha filmen autós üldözést lát, ha a hírekben balesetekröl hall, jelentös distresszt él át. Az alkalmazott kérdöívek tanúsága szerint Panna alig mutat depressziós (Beck Depresszió Skála 6p, normál) vagy általános szorongásos tüneteket (Beck Szorongás Leltár 17p, alacsony), poszttraumás stressztüneteket azonban igen, fóleg intruzí, kisebb részt hyperarousal jelleggel (Poszttraumás Stressz Diagnosztikai Skála 15p, közepes szintü zavar).

\subsection{Anamnézis}

Az EMDR strukturált terápiás módszer, amely nyolc szakaszból áll. Az első fázis, mint minden pszichoterápiás módszer esetében, az anamnézisfelvétel, amelynek során külön figyelmet szentelünk a potenciálisan traumatikus életeseményeknek, amelyek egyúttal a kezelés indikációját képezik. Meg kell állapítanunk azt is, hogy a bejelentkezés alapját adó tünetek akut streszszel, egyszeri traumával, ismétlódő megrázkódtatásokkal, vagy hosszantartó traumatizációval állnak-e kapcsolatban. Az esetkonceptualizáció után kidolgozzuk a kezelési tervet, amely a maladaptívan tárolt emlékek, a kiváltó ingerként (triggerként) ható jelen helyzetek és a szorongató jövőbeli szituációk feldolgozásán vezeti majd végig a klienst. Ez a fázis a terápiás kapcsolat kialakítására és megerósítésére is szolgál, amely - mint minden pszichoterápiában - az EMDR-kezelésben is nélkülözhetetlen.

Panna rendezett, értelmiségi családban, első gyermekként született vidéken. Az óvodát nehezen szokta meg, de az iskolába már könnyen beilleszkedett, tanulmányai rendben zajlottak, kortárskapcsolatai megfelelők voltak. Évekig táncolt és 
különböző hangszereken játszott. Egyetemre már nagyvárosba iratkozott, tanulmányait sikeresen végzi. Szüleivel való kapcsolata harmonikus, de függetlenségét élvezi, öccseiért szinte rajong. Két éve van egy barátja, kapcsolatuk támogató. Úgy érzi, élete egyetlen problémája a közlekedésfóbia, ami akadályozza mindennapi életvezetésében, szabadidős programokat sem tud szabadon tervezni, és tisztában van vele, hogy ha nem tud majd vezetni, az a munkavállalásban hátrányosan érintheti.

\subsection{Felkészítés}

A második szakasz a felkészítés, amelyben stabilizáljuk a kliens lelkiállapotát (ha szükséges), pszichoedukációban részesítjük a trauma természetéről és az EMDR-ről, majd bevezetjük a kezelések alatt alkalmazott technikába (BLS). Meg kell bizonyosodnunk arról, hogy a kliens lelkiállapota kellóképpen stabil, hogy a traumával való konfrontációt elbírja, ellenkező esetben nem történik feldolgozás, és kockáztatjuk az újratraumatizációt. Ez nem feltétlenül jelent teljes stabilitást - ez esetben nem volna szükség pszichoterápiára -, csak egyfajta "kettős tudatosságra” (dual awareness) való képességet: hogy a páciens egyszerre tudjon vezetésünkkel „fél lábbal a múltban, fél lábbal a jelenben" lenni. A kliensnek megfelelő önkontroll-stratégiákkal kell rendelkeznie ahhoz, hogy a traumafeldolgozás során - az ülések alatt vagy között - adódó átmeneti érzelmi hullámzásokat kezelni tudja, vagy ha ezeknek nincs birtokában, akkor meg kell tanítani erre. Alapvetően fontos eltalálni azt a teherbírási szintet, amelyen a traumákkal már szembesülhetünk, és ciklikusan vissza-visszatérni a stabilizáció fázisához, amikor szükséges. Ugyancsak fel kell mérni a kliens társas támogató rendszerét és segítségkérő képességét.

Panna esetében egyszeri traumával állunk szemben, amely azonban érzékeny korban érte. Egyéb traumának, rossz bánásmódnak nem volt részese. Rendezett életvezetésü, jó szociális hátterü, támogató társas kapcsolatokkal rendelkező személy, aki böven számíthat segitségre, ha egyensúlya átmenetileg megbillenne. Öngondoskodása megfelelö, erőforrásokkal (zene, tanulás) rendelkezik. Önreflexiója, énereje megvan. Bár érzékeny, affektustoleranciája megfelelö. Az EMDRterápiának érzelmi nyitottsággal és intellektuális kiváncsisággal néz elébe. A terápiás terv a következő elemek feldolgozását tartalmazza: a múltban a baleset, a járásképtelenség, a fémek kimütése, a birósági tárgyalás és végül a forgalomban való leblokkolás, a jelenben a mindennapi közlekedés utcán és autóban, bizonyos filmjelenetek, a jövőben pedig a jogositvány megszerzése és a félelem attól, hogy a probléma visszatér. 


\section{3. Értékelés}

Az EMDR-terápia harmadik szakaszában már egy adott eseménnyel (ún. targettel) dolgozunk, amelyet a páciens különböző szempontok alapján értékel. A szakasz célja, hogy a feldolgozandó emléket annak vizuális, kognitív, affektív és szomatikus komponensein keresztül aktiváljuk az újrafeldolgozáshoz. A kliens kiválasztja az esemény legrosszabb részét: ez lehet egy kép (például a szemben haladó sávból vészesen közeledő autó), egy hang (csattanás), esetleg egy testérzet (ahogy a kormány a mellkasába csapódik). Ezután a páciens megfogalmaz egy saját személyére vonatkozó negatív gondolatot, kedvezőtlen ítéletet, amelyet a feldolgozandó jelenet felidézése jelenleg kivált belóle (negatív kogníció, például „Rossz vagyok”, „Veszélyben vagyok", „Képtelen vagyok kiállni magamért”). Ezután megfogalmazza, hogy - adaptívan, reálisan - hogyan szeretne a későbbiekben önmagára tekinteni, ha a jelenetre gondol (pozitív kogníció, például "Jó vagyok úgy, ahogy vagyok", ,(Most már) biztonságban vagyok”, ,Ki tudom fejezni az igényeimet"). Ezután egy 1-től 7-ig terjedő skálán felmérjük, hogy mennyire érzi érvényesnek ezt a kijelentést most, vagyis a felidézés pillanatában (validity of cognition, $V o C$ ). A továbbiakban rákérdezünk a jelenethez tapadó negatív érzelmekre (például frusztráció, félelem, szégyen), és egy 0-tól 10-ig terjedő skálán felmérjük, hogy mennyire érzi a kliens megterhelőnek a jelenetet és a negatív kogníciót a kiértékelés pillanatában (subjective units of disturbance, SUD). Végül megkérdezzük, hol érzi mindezt a testében (például összeszorul a gyomra, gombóc van a torkában).

A feldolgozandó jelenet értékelése során a legkellemetlenebb pillanatnak Panna azt választja, amikor magához tér a földön, nem tudja, hol van, mi történt, és megpróbál fölállni, de nem tud. Negatív kogníciója: "Tehetetlen vagyok". Ehelyett szívesebben gondolna magára ezekkel a szavakkal: "Képes vagyok tenni valamit" (pozitív kogníció, ami nem a meg-nem-történtté tevés - például felállni, mintha mi sem történt volna -, hanem a realitás irányában hatva például arra vonatkozhat, hogy képes körülnézni vagy segítségért kiabálni). Ennek érvényességét az 1-töl 7-ig tartó skálán jelenleg 1-es szintünek érzi (VoC=1). Érzelmekként rémületet, szomorúságot, magányosságot fogalmaz meg. A megkérdezés pillanatában a jelenet maximálisan zavarja $(S U D=10)$. Testében erötlenséget érez, leginkább a lábában, de a gyengeség az egész testére kiterjed.

\subsection{Deszenzitizáció}

A traumás emlék aktiválását követően azonnal rátérünk az EMDR-terápia negyedik szakaszára, a BLS-t alkalmazó deszenzitizációra. A kliens engedi 
elméjét szabadon vándorolni, és megosztja velünk legutóbbi asszociációit, amikor megállítjuk. Szigorú protokoll szerint hol folytatjuk a BLS-t, hol viszszatérünk az eredeti jelenethez, időnként felmérve a SUD-skálán, hogyan változott a feldolgozandó jelenet negatív érzelmi töltete. Ezt mindaddig folytatjuk, amíg a SUD-érték minimálisra (0-ra vagy 1-re) csökken. A terapeuta a "szükséges és elégséges" beavatkozás elvét alkalmazza: kizárólag akkor interveniál, ha a folyamat elakad.

A baleset deszenzitizációja több ülésen keresztül zajlik. Panna érzelmi reakciói hullámzóak, a teljes elkeseredéstól a dühön át a fokozatos megnyugvásig. Felidéződnek benne az esemény részletei: a fájdalom, a kiszolgáltatottság, a szerencsétlenségérzés. Hangot kap a harag is: semmivel sem érdemelte ki, hogy ilyen rossz dolog történjen vele ilyen fiatalon. Hol volt Isten? Mennyire igazságtalan, hogy 22 évesen még ezzel kinlódik! Lassan pozitív asszociációk is beszüremkednek: egy föléje hajló részvétteljes arc, egy iskolatárs megnyugtató jelenléte, egy mobiltelefon, amelyről mentöt lehet hívni, a segitség gyors érkezése, a tény, hogy valójában elég hamar fölépült. Külön nehézséget jelent egy akadályozó háttérgondolat: ha elfogadja, hogy a baleset megtörtént, akkor azzal mintha felmentené a részeg sofört. A gondolat felszinre kerülésével bekövetkezhet annak adaptív átdolgozása: a belenyugvással nem azt fogadja el, hogy valaki ittasan autóba ül és ártatlanokat veszélyeztet, hanem azt, hogy balesetek sajnos elöfordulhatnak az életben. Eljátszik az időgép gondolatával, amellyel visszaforgathatná az események láncolatát, de el is engedi ezt a fantáziát. Felnött énje nyugtatja a földön fekvöt, hogy lám, Isten mégis ott volt, mert nem hagyta meghalni. Rájön, hogy nem tört derékba az élete, sokan látogatták, sok támogatást kapott. Végül a jelenet természetesen nem kellemes számára, de már nem zavarja.

\subsection{Installáció}

A kezelés következő szakasza a pozitív állítás megerősítése. A klienstől ismét megkérdezzük, mennyire érzi azt érvényesnek, amikor a jelenetre gondol, majd folytatjuk a BLS-t mindaddig, míg a kijelentés érvényessége (VoC) optimálisra (7-re) emelkedik.

Panna pozitív kogníciójának ("Képes vagyok tenni valamit”) érvényessége már a deszenzitizációt követôen is emelkedik (VoC=3). Racionálisan belátja, hogy nem várhat el magától aktív cselekvést egy súlyos balesetet követöen. Az installáció során eljut addig a felismerésig, hogy megtette, amire képes volt: nem "hisztizett", nyugodtan megvárta, amíg megérkezik a segitség, képes volt válaszolni a mentök kérdéseire, és végrehajtani utasitásaikat. 


\subsection{Testérzések monitorozása}

Az eljárás hatodik szakasza a testérzések ellenőrzése, hiszen a test őrizheti még a sérelmek lenyomatát az után is, hogy az elme megbékélt velük (van der Kolk, 2014). A klienst megkérjük, hogy az eredeti jelenet és a pozitív kogníció felidézése közben pásztázza végig a testét. A BLS-t addig folytatjuk, amíg az esetleges szokatlan, kellemetlen testérzetek vagy negatív asszociációk meg nem szúnnek.

Panna balesetben eltört lábában sokáig mindenféle érzetek jelentkeznek: bizsergés, zsibbadás vagy az, hogy végtagját eltérönek érzi a másiktól. Nem biztos benne, hogy csak képzeli-e, vagy tényleg látta törött csontját kidudorodni a balesetkor. Eszébe jut, milyen sokáig megérezte az idôváltozásokat, és hogy a lába még mindig tud fájni, ha fáradt. Zavarja, hogy nem képes teljesen elengedni magát, ha masszirozzák, mert tart tőle, hogy fájni fog, de érzi a fejlődést, mert korábban egyáltalán nem türte ezen a lábán az érintést. A bilaterális stimulációval párhuzamosan furcsa testérzései és negatív asszociációi fokozatosan elmaradnak, már csak fáradtságról, majd kellemes elernyedésról számol be.

\subsection{Lezárás}

Az ülés lezárásakor megbizonyosodunk, hogy a kliens megfelelően stabil lelkiállapotban hagyja el a rendelőt, és pozitív hozadékot képes magával vinni. Távozása elótt megkérjük, hogy a következő alkalomig jegyezzen fel minden olyan gondolatot, felismerést, álmot, felbukkanó emléket, reakciót, viselkedést, ami érzése szerint kapcsolatba hozható azzal, amin éppen dolgoztunk.

A terápia elörehaladtával Panna két ülés közt pozitív változásokat vesz észre magán. Eleinte már az is nagy eredménynek számít, hogy nem ijed meg, ha a zebrán még a járdára lépés előtt meghallja, hogy a vezetố gázt ad. Késóbb egy megbizható rokon, majd egy távoli ismerős autójába is be mer ülni, és komolyan elgondolkodik, hogy átszalad egy négysávos úton, mert messze van a zebra. Végül nem teszi, de nem félelemböl, hanem bölcs óvatosságból.

\section{8. Újraértékelés}

A nyolcadik fázis a következő ülés elején zajló újraértékelés. Ha a feldolgozás az előző ülésen nem fejeződött be, folytatjuk. Ha befejeződött, akkor rátérünk a kezelési terv következő feldolgozandó elemére. A fentebb leírt eljá- 
rássorozatot mindaddig ismételjük, amíg a terápiás terv összes elemét fel nem dolgoztuk. Ezután az EMDR-terápia lezárható.

A balesetjelenet feldolgozása után sorban következik a többi emlék. Panna idóközben rossz élményt is átél: egy szinházi előadáson a fóhős - aki épp az ő keresztnevét viseli - autóbalesetet szenved. A színdarab annyira felzaklatja, hogy ki kell jönnie a színházból, majd egész este zokog. Ezt az esetet felvesszük a jelenbeli kiváltó ingerek közé, és a maga idejében ezt is feldolgozzuk. Pannát lassan már nem akadályozza semmi a közlekedésben: pedállal hajtható sétakocsit vezet egy pihenöparkban, majd biciklitúrára is elmegy, és nem ijed meg a mellette elhajtó busztól. A terápiát az élet is segiti: az utcán meglátja az ismerőst, aki ott volt a baleset helyszinén, és erős késztetést érez, hogy elmondja, azóta már minden rendben vele. Panna terápiájának lezárásakor a Poszttraumás Stressz Diagnosztikai Skála pontszáma (3p) töredéke a kezdő értéknek (15p). Panna már alig várja, hogy vezessen, a vizsgaidöszak végeztével el is kezdi.

A fent bemutatott esetleírás jól illusztrálja az EMDR-terápia folyamatát. Tipikusnak mondható például, hogy itt is a kulcsemlékként szolgáló első trauma - maga a baleset - feldolgozása jelentette a terápia leghosszadalmasabb részét. Miután a trauma velejét képező kulcsemlék megoldódik, a folyamat a legtöbb esetben felgyorsul, és mire a jelenbeli problémás helyzetekhez ér, többnyire már azok száma is csökken. A mindennapi gyakorlatra szintén jellemző, ahogy a deszenzitizáció és az installáció fázisában a várható ütemben, sorrendben és arányban jöttek a negatív és pozitív asszociációk, a feldolgozás haladt a maga mentén, és csak akkor kellett beavatkozni, amikor a folyamatot egy háttérmeggyőződés akadályozta. Nincs semmi kivételes abban sem, hogy a terápiával párhuzamosan zajlik az élet, a pácienst külső hatások érik, amelyek közül egynéhány jelezheti, mely területen maradt még tennivaló.

A fenti esetben speciálisnak tekinthető, hogy egy baleset ugyan egyszeri traumának számít, mégis olyan mély nyomot hagyott a páciens személyiségében - vélhetóleg zsenge életkora és érzékeny lelkülete miatt - ami meghosszabbította a terápiát. Ha a baleset felnőttkorában érte volna, 5-7 alkalom is elég lehetett volna poszttraumás stressz zavara kezelésére, ám így Panna teljes, nyolc szakaszt átölelő terápiája tizenhét 75-perces ülést vett igénybe. Szintén sajátosnak számított a testérzések monitorozásának szakasza: míg más esetekben ez egy általában gyorsan zajló biztonsági szakasz a fennmaradó kellemetlen érzetek semlegesítésére, Panna esetében a szokásosnál tovább tartott, feltehetóleg azért, mert a trauma nagymértékben érte a testét is. Összességében a fenti leírás olyan esetet illusztrál, amellyel - a maga egyedi színfoltjaival együtt - a gyakorló EMDR-terapeuta bármikor találkozhat. 


\section{Az EMDR-terápia hatása}

A félelemcsökkenés jelei már a beavatkozás kezdetén meg szoktak mutatkozni. Az eredeti emlékhez való visszatéréskor a kliensek reakciói a kezelés távolító hatásáról árulkodnak: hogy most mintha kívülről, felülről vagy messzebbről, esetleg üvegfalon túlról, elmosódottan látnák a jelenetet, a színek kifakultak, az alakok kisebbnek, távolibbnak hatnak. Néha úgy fest a jelenet, mintha csak egy kép lenne a falon, vagy egy fekete-fehér videófelvétel. Máskor a jelenet változatlan, csak épp kevésbé fenyegető, vagy akár teljesen ártalmatlan, olykor nevetséges. Akárhogyan is, deszenzitizáció után a kliens képessé válik distressz nélkül ránézni a jelenetre.

A deszenzitizációt gyakran belátás követi: új aspektusok kerülnek előtérbe, a traumatikus eseményre más fény vetül. Az oktulajdonítások funkcionális irányba tolódnak, a felelősségek reálisan oszlanak meg, a történet koherensebbé válik, és új jelentéseket kap. A kliensek meg szoktak lepődni, hogy az aktiválódott emlékhálózatokból milyen látszólag nem oda tartozó, mégis releváns csomópontok bukkannak föl („Ez most hogy jutott eszembe?"). Vagyis: a traumás emlék az adaptív memóriahálózatokhoz kapcsolódik, és megtörténik az újrafeldolgozás. A kliens saját megoldásaira talál rá, amelyek sokszor bölcsebbek a mégoly invenciózus terápiás beavatkozásoknál.

A trauma éppen attól trauma, hogy spontán felidéződése olyan, mintha az illető újra meg újra belépne az esemény örökösen rémisztő, fájdalmas jelenébe. Egy sikeres EMDR-terápia során a traumából egyszerú rossz emlék lesz, amiről a kliens úgy tud beszélni, mint élete más eseményéről, amely megtörténtekor szörnyú volt, de ma már nem okoz szenvedést, mert megtalálta helyét (egy kliens megfogalmazásában: „elkönyvelt tény lett”) az élettörténetben. Az esetek egy részében a folyamat nem is áll meg itt, hanem továbbhalad a poszttraumás növekedés irányába (Jeon és mtsai, 2017), amelynek során a személyiség megerősödve, egy új szinten újjászerveződve kerül ki.

\section{Az EMDR helyzete, jövơje a világban és itthon}

Megjelenése után három évtizeddel az EMDR ma már jelentős intézményi és szakmai háttérrel rendelkezik. Világszervezete, az EMDRIA (EMDR International Association) 1995-ben alakult. Ezt követte 1999-ben az EMDR Europe, amelynek jelenleg 27 európai ország (köztük hazánk is) és Izrael képezi tagságát. A terápiás módszernek 2007 óta saját szakmai folyóirata van (Journal of EMDR Practice and Research), amelyet a Springer ad ki. 
Az EMDR önmeghatározásához szorosan hozzátartozik a humanitárius segítségnyújtás: készenléti hálózat áll rendelkezésre a világ minden táján természeti katasztrófák (pl. földrengések, cunamik) vagy ember által okozott (háborúk, népirtások, balesetek, terrorista) cselekmények esetére, amelyekben közvetlen segítséget lehet kérni a világszervezettől (www. emdrhap.org). Az azonnali beavatkozás módszertanát illetően külön protokoll áll a szakemberek rendelkezésére, amelynek hatásosságát szintén randomizált kontrollált vizsgálat támasztja alá (Acarturk és mtsai, 2016). A tragikus 2017-es veronai buszbaleset túlélőinek és hozzátartozóiknak például EMDR-terapeuták is segítettek mind Olaszországban, mind itthon (V. Komlósi \& Richter, 2017).

A Magyar EMDR Egyesület 2013-ban alakult, jelenleg több mint 100 tagja van, és a kiképzett magyar EMDR-terapeuták száma lassan eléri a 20-at (www.emdr.hu). A magyar képzési előírások meglehetósen szigorúak: a bemeneti feltétel szerint a tanulmányait megkezdő szakembernek legalább tanácsadó szakpszichológusnak, klinikai szakpszichológus(jelölt)nek vagy pszichiáter szakorvos(jelölt)nek kell lennie, és egy, a Pszichoterápiás Grémium által akkreditált módszerspecifikus képzésnek legalább szupervíziós szakaszában kell tartania. Az EMDR Europe által elismert EMDR-terapeuta címet csak befejezett szakképzéssel és természetesen a képzés kimeneti feltételeinek eleget téve lehet átvenni. Ez hivatott biztosítani a szakemberek felkészültségét arra, hogy akár súlyosan, többszörösen traumatizált, komplex esetekkel is tudjanak dolgozni.

Az EMDR-ről készült első, 2004-es magyar beszámoló szerzője még nem önálló módszerként, hanem "sajátos pszichotraumatológiai technikaként" utalt az EMDR-re, amelyet a terapeuta az általa alkalmazott pszichoterápiás keretbe integrál (Oravecz, 2004, 506. o.). A második és ezidáig utolsó szakmai ismertetés már "teljes értékú terápiás módszerként" hivatkozik rá (Havelka, 2015, 294. o.). Arra is fel kell hívnunk a szakemberek figyelmét, hogy az EMDR nem azonos egyéb, adott esetben BLS-t is alkalmazó eljárásokkal, mint például a wingwave coaching vagy az EFT nevú ún. „kopogtató módszer" (Ortner, 2013).

\section{7. Összefoglalás}

Az EMDR integratív eljárás, amelyben felismerhetők bizonyos pszichodinamikus, kognitív és hipnoterápiás elemek, sőt, akár ősi szenvedésenyhítő eljárások (ritmikus mozgásformák, ingó tárgyak szemmel követése) is. Mindazonáltal, az EMDR nemcsak ismert és eredeti elemek újszerú kombinációja, nem is a már meglévő traumakezelési eljárások technikai kiegé- 
szítése, hanem teljes értékú, önálló pszichoterápiás módszer, saját elméleti modellel, hatásmechanizmussal és eszköztárral. EMDR során egyebek közt deszenzitizáció, valamint egy olyan folyamat zajlik, amely aktiválja az agy adaptív információfeldolgozó rendszereit. Specifikus hatótényezője a bilaterális ingerlés, amely a nyolc szakaszból álló terápia nem minden fázisának sajátja.

Az EMDR-módszer több egyszerú stresszcsökkentésnél: fokozza a sokféle patológiát (PTSD-t, pánikzavart, depressziót, kényszerbetegséget, fóbiát, stb.) előidézhet”, „,befagyott” traumás emlékekhez való hozzáférést, ezzel elősegítve újrafeldolgozásukat. Sikeres EMDR-terápia hatására a személy napirendre tér az életútját megakasztó események felett, és beemeli őket egy olyan egységes narratívába, amely hozzájárul személyisége élethosszig tartó éréséhez és integrációjához.

\section{Irodalom}

Acarturk, C., Konuk, E., Cetinkaya, M., Senay, I., Sijbrandij, M., Gulen, B., et al. (2016). The efficacy of eye movement desensitization and reprocessing for post-traumatic stress disorder and depression among Syrian refugees: results of a randomized controlled trial. Psychological Medicine, 46, 2583-2593.

American Psychiatric Association (2013). Diagnostic and statistical manual of mental disorders. (5th ed.). DSM-5 ${ }^{\mathrm{TM}}$. Washington DC, London: American Psychiatric Publishing

American Psychological Association (2017). Clinical Practice Guideline for the Treatment of PTSD in Adults. Adopted as APA Policy February 24, 2017. Letöltve: 2018. 02. 24-én: http://www.apa.org/ptsd-guideline/index.aspx

Andrade, J., Kavanaugh, D., Baddeley, A. (1997). Eye-movements and visual imagery: A working memory approach to the treatment of post-traumatic stress disorder. British Journal of Clinical Psychology, 36, 209-223.

Barrowcliff, A.L., Gray, N.S., Freeman, T.C.A., \& MacCulloch, M.J. (2004). Eye movements reduce the vividness, emotional valence and electrodermal arousal associated with negative autobiographical memories. Journal of Forensic Psychiatry and Psychology, 15(2), 325-345.

Bergmann, U. (2010). EMDR's neurobiological mechanisms of action: A survey of 20 years of searching. Journal of EMDR Practice and Research, 4(1), 22-42.

Chen, Y.R., Hung, K.W., Tsai, J.C., Chu, H., Chung, M.H., Chen, S.R., et al. (2014). Efficacy of Eye-Movement Desensitization and Reprocessing for patients with posttraumatic stress disorder: A meta-analysis of randomized controlled trials. PLoS ONE, 9(8): e103676. Doi: 10.1371/journal.pone.0103676

Davidson, P.R., \& Parker, K.C.H. (2001). Eye movement desensitization and reprocessing (EMDR): A meta-analysis. Journal of Consulting and Clinical Psychology, 69, 305-316.

Elofsson, U.O.E., von Scheele, B., Theorell, T., \& Söndergaard, H.P. (2008) Physiological correlates of eye movement desensitization and reprocessing. Journal of Anxiety Disorders, 22(4), 622-634.

Engelhard, I.M., van den Hout, M.A., \& Smeets, M.A.M. (2011). Taxing working memory reduces vividness and emotional intensity of images about the Queen's Day tragedy. Journal of Behavior Therapy and Experimental Psychiatry, 42, 32-37. 
Fonagy, P., Gergely, Gy., Jurist, E.L., \& Target, M. (2002). Affect regulation, mentalization, and the development of the self. New York: Other Press

Gunter, R.W., \& Bodner, G.E. (2008). How eye movements affect unpleasant memories: Support for a working memory account. Behavior Research and Therapy, 46, 913-931.

Gunter, R.W., \& Bodner, G.E. (2009). EMDR works... but how? Recent progress in the search for treatment mechanisms. Journal of EMDR Practice and Research, 3(3), 161-168.

Havelka, J. (2015). EMDR (Eye Movement Desensitization \& Reprocessing). Újrafeldolgozási terápia bilaterális ingerléssel In: Kuritárné Szabó Ildikó \& Tisljár-Szabó Eszter (szerk.) Úgy szerettem volna, ha nem bántottak volna. A családon belüli gyermekkori traumatizáció: Elmélet és terápia (291-312). Budapest: Oriold és Társai

Herman, J.L. (2003). Trauma és gyógyulás. Budapest: Háttér Kiadó - Kávé Kiadó - NANE Egyesület

Hornsveld, H.K., Landwehr, F., Stein, W., Stomp, M.P.H., Smeets, M.A.M., \& van den Hout, M.A. (2010). Emotionality of loss-related memories is reduced after recall plus eye movements but not after recall plus music or recall only. Journal of EMDR Practice and Research, 4(3), 106-112.

Horst, F., Den Oudsten, B., Zijlstra, W., de Jongh, A., Lobbestael, J., \& De Vries, J. (2017). Cognitive behavioral therapy vs. Eye movement desensitization and reprocessing for treating panic disorder: A randomized controlled trial. Frontiers in Psychology, 8:1409. Doi: 10.3389/fpsyg.2017.01409

Högberg, G., Pagani, M., Sundin, O., Soares, J., Aberg-Wistedt, A., Tärnell, B., et al. (2007). On treatment with eye movement desensitization and reprocessing of chronic posttraumatic stress disorder in public transportation workers: A randomized controlled study. Nordic Journal of Psychiatry, 61(1), 54-61.

Jaberghaderi, N., Greenwald, R., Rubin, A., Dolatabadim S., \& Zand, S.O. (2004). A comparison of CBT and EMDR for sexually abused Iranian girls. Clinical Psychology and Psychotherapy, 11, 358-368.

Jeon, S.W., Han, C., Choi, J., Ko, Y.H., Yoon, H.K., \& Kim, Y.K. (2017). Eye Movement Desensitization and Reprocessing to facilitate posttraumatic growth: A prospective clinical pilot study on ferry disaster survivors. Clinical Psychopharmacology and Neuroscience, 15(4), 320-327.

Konuk, E., Knipe, J., Eke, I., Yuksek, H., Yurtsever, A., \& Ostep, S. (2006). The effects of EMDR therapy on post-traumatic stress disorder in survivors of the 1999 Marmara, Turkey, earthquake. International Journal of Stress Management, 13, 291-308.

Lamprecht, F., Kohnke, C., Lempa, W., Sack, M., Matzke, M., \& Munte, T. (2004). Eventrelated potentials and EMDR treatment of post-traumatic stress disorder. Neuroscience Research, 49, 267-272.

Lansing, K., Amen, D.G., Hanks, C., \& Rudy, L. (2005). High resolution brain SPECT imaging and EMDR in police officers with PTSD. Journal of Neuropsychiatry and Clinical Neurosciences, $17,526-532$.

Lee, C.W., \& Cuijpers, P. (2013). A meta-analysis of the contribution of eye movements in processing emotional memories. Journal of Behavior Therapy and Experimental Psychiatry, 44, 231-239.

Levin, P., Lazrove, S., \& van der Kolk, B.A. (1999). What psychological testing and neuroimaging tell us about the treatment of posttraumatic stress disorder (PTSD) by eye movement desensitization and reprocessing (EMDR). Journal of Anxiety Disorders, 13, 159-172.

MacCulloch, M.J., \& Feldman, P. (1996). Eye movement desensitization treatment utilizes the positive visceral element of the investigatory reflex to inhibit the memories of posttraumatic stress disorder: A theoretical analysis. British Journal of Psychiatry, 169, 571-579. 
Marcus, S., Marquis, P., \& Sakai, C. (1997). Controlled study of treatment of PTSD using EMDR in an HMO setting. Psychotherapy, 34, 307-315.

Marcus, S., Marquis, P., \& Sakai, C. (2004). Three- and 6-month follow-up of EMDR treatment of PTSD in an HMO setting. International Journal of Stress Management, 11, 195-208.

Maxfield, L., Melnyk, W.T., \& Gordon Hayman, C.A. (2008). A working memory explanation for the effects of eye movements in EMDR. Journal of EMDR Practice and Research, 2(4), 247-261.

Nader, K., Schafe, G.E., \& Le Doux, J.E. (2000). Fear memories require protein synthesis in the amygdala for reconsolidation after retrieval. Nature, 406(6797), 722-726.

National Institute for Health and Care Excellence (2005). Post-traumatic stress disorder: management. Clinical guideline. Published: 23 March 2005. Letöltve: 2018. 02. 24-én: www. nice.org.uk/guidance/cg26

Navarro, P.N., Landin-Romero, R., Guardiola-Wanden-Berghe, R., Moreno-Alcázar, A., Valiente-Gómez, A., Lupoh, W., et al. (2018). 25 years of Eye Movement Desensitization and Reprocessing (EMDR): The EMDR therapy protocol, hypotheses of its mechanism of action and a systematic review of its efficacy in the treatment of post-traumatic stress disorder. Revista de Psiquiatría y Salud Mental, 11(2), 101-114.

Oh, D.-H., \& Choi, J. (2007). Changes in the regional cerebral perfusion after Eye Movement Desensitization and Reprocessing: A SPECT study of two cases. Journal of EMDR Practice and Research, 1(1), 24-30.

Oravecz, R. (2004). A gyermekkori szexuális abúzus kezelése és következményei Addiktológia, $3(4), 498-514$.

Ortner, N. (2013). EFT - A kopogtató módszer. Forradalmi megoldások a stresszmentes életért. Budapest: Bioenergetic Kft.

Ostacoli, K., Carletto, S., Cavallo, M., Baldomir-Gago, P., Di Lorenzo, G., Fernandez, I., et al. (2018). Comparison of Eye Movement Desensitization Reprocessing and Cognitive Behavioral Therapy as adjunctive treatments for recurrent depression: The European Depression EMDR Network (EDEN) randomized controlled trial. Frontiers in Psychology, 9, 74. Doi: 10.3389/fpsyg.2018.00074

Pagani, M., Di Lorenzo, G., Monaco, L., Daverio, A., Giannoudas, I., La Porta, P., et al. (2015). Neurobiological response to EMDR therapy in clients with different psychological traumas. Frontiers in Psychology, 6, 1614. Doi: http:/ / dx.doi.org/10.3389/fpsyg.2015.01614

Power, K.G., McGoldrick, T., Brown, K., Buchanan, R., Sharp, D., Swanson, V., et al. (2002). A controlled comparison of eye movement desensitization and reprocessing versus exposure plus cognitive restructuring, versus waiting list in the treatment of posttraumatic stress disorder. Journal of Clinical Psychology and Psychotherapy, 9, 299-318.

Propper, R.E., \& Christman, S.D. (2008). Interhemispheric interaction and saccadic horizontal eye movements: Implications for episodic memory, EMDR, and PTSD. Journal of EMDR Practice and Research, 2, 269-281.

Sack, M., Lempa, W., \& Lamprecht, F. (2007). Assessment of psychophysiological stress reactions during a traumatic reminder in patients treated with EMDR. Journal of EMDR Practice and Research, 1(1), 15-23.

Salkovskis, P. (2002). Commentary on Review: eye movement desensitisation and reprocessing is not better than exposure therapies for anxiety or trauma. Evidence-Based Mental Health, 5: 13. Doi: $10.1136 /$ ebmh.5.1.13

Seidler, G.H., \& Wagner, F.E. (2006). Comparing the efficacy of EMDR and trauma-focused cognitive-behavioral therapy in the treatment of PTSD: a meta-analytic study. Psychological Medicine, 36, 1515-1522. 
Shapiro, F. (1989). Efficacy of the eye movement desensitization procedure in the treatment of traumatic memories. Journal of Traumatic Stress, 2(2), 199-223.

Shapiro, F. (2001). Eye movement desensitization and reprocessing. Basic principles, protocols, and procedures. New York, NY: Guilford

Shapiro, F. (2016). Gyözd le a múltad! Budapest: Medicina

Smith, N.B., Doran, J.M., Sippel, L.M., Harpaz-Rotem, I. (2017). Fear extinction and memory reconsolidation as critical components in behavioral treatment for posttraumatic stress disorder and potential augmentation of these processes. Neuroscience Letters, 649, 170-175.

Stickgold, R. (2002). EMDR: A putative neurobiological mechanism of action. Journal of Clinical Psychology, 58(1), 61-75.

Thomaes, K., Engelhard, I.M., Sijbrandij, M., Cath, D.C., \& Van den Heuvel, O.A. (2016). Degrading traumatic memories with eye movements: a pilot functional MRI study in PTSD. European Journal of Psychotraumatology, 7, 31371. Doi: 10.3402/ejpt.v7.31371

Tulving, E., Kapur, S., Craik, F.I.M., Moscovitch, M., \& Houlet, S. (1994). Hemispheric encoding/retrieval asymmetry in episodic memory: Positron emission tomography findings. Proceedings of the National Academy of Sciences of the United States of America, 91, 2016-2020.

V. Komlósi, A., \& Richter, J. (2017). Hungarian bus accident in Italy. Lessons learned. Paper presented at the European Federation of Psychologists' Associations Symposium, Bern, May 19, 2017. Letöltve: 2018. 01. 28-án: http:/ / disaster.efpa.eu/information/2017-bernsymposium-lessons-learned-from-the-european-countries/

van den Hout, M.A., Engelhard, I.M., Rijkeboer, M.M., Koekebakker, J., Hornsveld, H., Leer, A., et al. (2011). EMDR: Eye movements superior to beeps in taxing working memory and reducing vividness of recollections. Behaviour Research and Therapy, 49, 92-98.

van der Kolk, B., Pynoos, R., Cicchetti, D., Cloitre, M., D'Andrea, W., Ford, J., et al. (2009). Proposal to include a Developmental Trauma Disorder Diagnosis for children and adolescents in DSM-V. Submitted February 1, 2009. Letöltve: 2018. 01. 19-én: http:/ / www.traumacenter.org/announcements/dtd_papers_oct_09.pdf

van der Kolk, B.A. (2014). The body keeps the score. Brain, mind, and body in the healing of trauma. New York: Penguin

van der Kolk, B.A., \& Fisler, R. (1996). Dissociation and the fragmentary nature of traumatic memories: Overview. British Journal of Psychotherapy, 12(3), 352-361.

van der Kolk, B.A., Spinazzola, J., Blaustein, M.E., Hopper, J.W., Hopper, E.K., Korn, D.L., et al. (2007). A randomized clinical trial of eye movement desensitization and reprocessing (EMDR), fluoxetine, and pill placebo in the treatment of posttraumatic stress disorder: treatment effects and long-term maintenance. Journal of Clinical Psychiatry, 68(1), 37-46.

Watts, B.V., Schnurr, P.P., Mayo, L., Young-Xu, Y., Weeks, W.B., \& Friedman, M.J. (2013). Meta-analysis of the efficacy of treatments for posttraumatic stress disorder. Journal of Clinical Psychiatry, 74, e541-550. Doi: 10.4088/JCP.12r08225

Wilson, D.L., Silver, S.M., Covi, W.G., \& Foster, S. (1996). Eye movement desensitization and reprocessing: Effectiveness and autonomic correlates. Journal of Behavior Therapy and Experimental Psychiatry, 27(3), 219-229.

Wolpe, J. (1990). The practice of behavior therapy (4th ed.). New York: Pergamon Press

World Health Organization (2013). Guidelines for the management of conditions specifically related to stress. Geneva: WHO 


\title{
Köszönetnyilvánítás
}

Hálával tartozom Dr. Bódizs Róbert pszichológus-alváskutatónak, valamint Dr. Havelka Judit, Richter Júlia, Steinberg Johanna és Vincze Ágnes klinikai szakpszichológusoknak jelen tanulmány korábbi változatához fúzött segítő megjegyzéseikért, valamint páciensemnek a közléshez való hozzájárulásáért.

\section{Nyilatkozat érdekütközésról}

A szerző ezúton kijelenti, hogy esetében érdekütközések nem állnak fenn.

\section{Eye Movement Desensitization and Reprocessing (EMDR) therapy in trauma: Effect, effectiveness and mechanisms of action}

\author{
SZIGETI F., JUDIT
}

Theoretical background: Eye Movement Desensitization and Reprocessing (EMDR) has been used as a psychotherapeutic method for 30 years. The procedure developed by Francine Shapiro in the late 1980's in the United States was first widely disputed, but is now an evidence-based method in the treatment of posttraumatic stress disorder (PTSD). Its use is increasing in several other mental disorders as well, such as panic disorder, depression and obsessive-compulsive disorder. In Hungary, the method is not widely used yet. Aim: A presentation of the history, theoretical background, hypotheses referring to the mechanisms of action, structure and effects of EMDR therapy. Method: Systematic review of the literature through keyword search using the name of the method in English-language databases (ISI Web of Science, PubMed, Scopus, PsycINFO). The overview focuses mainly on review articles or on studies of high-quality evidence (e.g. randomized controlled trials). Results: Desensitization, a better access to trauma memories and deeper informationprocessing take place during EMDR, resulting not only in stress reduction, but also in a more adaptive, higher-level functioning. Neuroimaging reveals that bilateral stimulation, EMDR's specific factor, brings about parasympathetic activation, and induces favorable changes in the functioning of the brain structures affected by PTSD. Several hypotheses (e.g. deconditioning, working memory, REM-hypothesis) have been suggested for EMDR's mechanisms of action. Most probably, the procedure involves several active components. After successful EMDR-therapy, individuals come to terms with the events disrupting their life course, and include them into a unified narrative, which may contribute to the integration of the personality. Conclusions: EMDR is not just a novel combination of wellknown and original therapeutic elements, nor a technical adjunct to existing schools of trauma therapy, but an evidence-based, full-fledged, integrative yet independent psychotherapeutic method, with a theoretical model, mechanisms of action and assets of its own.

Keywords: trauma, psychotherapy, posttraumatic stress disorder, eye movement desensitization and reprocessing, EMDR 